DOI: $10.19195 / 0524-4544.326 .14$

\author{
JAKUB CZUDIAK
}

Dolnośląski Urząd Wojewódzki we Wrocławiu

\title{
Krajowy system ratowniczo-gaśniczy w zarządzaniu kryzysowym
}

System bezpieczeństwa wewnętrznego państwa jest zbiorem wzajemnie się przenikających, współdziałających lub funkcjonujących równolegle podsystemów. Jest to zbiór elementów i funkcji, których odpowiednie połączenie ma decydujący wpływ na prawidłowe działanie całości. System, jego podsystemy, ich poszczególne elementy ulegają modyfikacjom, są reformowane, przekształcane. Istotą wszelkich zmian - przy założeniu, że co do zasady działania tych systemów i wobec systemów są nacechowane postępowaniem dla dobra państwa, a przede wszystkim na rzecz dobra obywatela, jednostki - jest postępowanie logiczne, którego skutkiem ma być ulepszenie już istniejącego stanu. Bezpieczeństwo to dobro wspólne ${ }^{1}$. Systemy, które działają na rzecz bezpieczeństwa, są także dobrem wspólnym.

Na początku lat 90. ubiegłego wieku Polska weszła w okres ogromnych, wielowarstwowych przemian, które dotyczyły wszystkich aspektów funkcjonowania kraju, w tym także obszaru bezpieczeństwa zewnętrznego i wewnętrznego. Kształtowane było nowe środowisko bezpieczeństwa, trwały prace nad strategicznymi koncepcjami w sferach obronności, ochrony ludności, bezpieczeństwa publicznego. Powódź, która miała miejsce w Polsce w 1997 roku, oprócz skutków społecznych i gospodarczych, miała także znaczenie dla pogłębienia - trwającej już od ponad siedem lat - dyskusji na temat kształtu bezpieczeństwa wewnętrznego, przede wszystkich określenia zadań i kompetencji organów państwa w zakresie bezpieczeństwa mieszkańców. Ponadto czas powodzi nałożył się na okres trwających już w kraju zmian, a co więcej, w rok po powodzi rozpoczęto wdrażanie czterech dużych reform — oświatowej, emerytalnej, ochrony zdrowia

${ }^{1} \mathrm{~J}$. Boć, O bezpieczeństwie wewnętrznym, [w:] Bezpieczeństwo wewnętrzne w działaniach terenowej administracji publicznej, red. A. Chajbowicz, T. Kocowski, Wrocław 2009, s. 21. 
i administracyjnej, mających ogromny wpływ na działanie i sposób zarządzania państwem.

W tym czasie w systemie bezpieczeństwa wewnętrznego był już widoczny, chociaż funkcjonował dopiero od kilku lat, krajowy system ratowniczo-gaśniczy, nazywany zwyczajowo KSRG.

Krajowy system ratowniczo-gaśniczy ma umocowanie prawne w ustawie z 24 sierpnia 1991 roku o ochronie przeciwpożarowej ${ }^{2}$ oraz ustawie z dnia 24 sierpnia 1991 roku o Państwowej Straży Pożarnej³ . Definicja tego systemu jest precyzyjnie określona w przepisie prawa, który stanowi, że krajowy system ratowniczo-gaśniczy to integralna część organizacji bezpieczeństwa wewnętrznego państwa, obejmującą, w celu ratowania życia, zdrowia, mienia lub środowiska, prognozowanie, rozpoznawanie i zwalczanie pożarów, klęsk żywiołowych lub innych miejscowych zagrożeń. System skupia jednostki ochrony przeciwpożarowej, inne służby, inspekcje, straże, instytucje oraz podmioty, które dobrowolnie w drodze umowy cywilnoprawnej zgodziły się współdziałać w akcjach ratowniczych ${ }^{4}$. Zaczął funkcjonować od 1995 roku, a jego organizatorem jest Państwowa Straż Pożarna. Podstawowym założeniem w budowie systemu ratowniczo-gaśniczego było stworzenie jednolitego i spójnego układu skupiającego powiązane z sobą różne podmioty ratownicze tak, aby można było skutecznie podjąć każde działanie ratownicze. System ten to zespół przedsięwzięć organizacyjno-planistycznych, szkoleniowych i materialno-technicznych, realizowanych przez komendantów Państwowej Straży Pożarnej, podległe i podporządkowane im siły i środki, a także inne podmioty, które wchodzą w skład tego systemu. Głównym celem KSRG jest zapewnienie ochrony życia, zdrowia, mienia lub środowiska, w ramach działań podejmowanych przez PSP i inne podmioty ratownicze (ze szczególnym uwzględnieniem OSP). Jest to realizowane poprzez gaszenie pożarów, likwidację innych miejscowych zagrożeń, ratownictwo chemiczne i ekologiczne, ratownictwo techniczne oraz ratownictwo medyczne w zakresie udzielania kwalifikowanej pierwszej pomocy.

Krajowy system ratowniczo-gaśniczy w ramach posiadanych sił i środków współpracuje z właściwymi organami i podmiotami podczas zdarzeń nadzwyczajnych wywołanych zagrożeniem czynnikiem biologicznym, w tym podczas zdarzeń o charakterze terrorystycznym. System opiera się na Państwowej Straży Pożarnej, wiodącej i utrzymywanej z budżetu państwa służbie ratowniczej, jak również Ochotniczych Strażach Pożarnych, utrzymywanych z budżetów samorządowych i dotacji z budżetu państwa. Centralnym organem administracji rządowej

${ }^{2}$ Ustawa z dnia 24 sierpnia 1991 roku o ochronie przeciwpożarowej (tekst jedn. Dz.U. z 2018 r. poz. 620, ze zm.). Opracowanie zawiera wyniki badań przeprowadzonych na podstawie praktycznego doświadczenia autora.

${ }^{3}$ Ustawa z dnia 24 sierpnia 1991 roku o Państwowej Straży Pożarnej (tekst jedn. Dz.U. z 2018 r. poz. 1313 ze zm.).

${ }^{4}$ Ustawa z dnia 24 sierpnia 1991 roku o ochronie przeciwpożarowej, art. 2 pkt 4. 
w sprawach organizacji KSRG oraz ochrony przeciwpożarowej jest Komendant Główny PSP. Podlega on ministrowi właściwemu do spraw wewnętrznych, który pełni nadzór nad funkcjonowaniem KSRG. System działa na trzech poziomach administracyjnych odpowiadających strukturze administracyjnej kraju:

— powiatowym — który jest podstawowym poziomem wykonawczym, a działania prowadzone są przez siły i środki powiatu;

— wojewódzkim — który koordynuje i wspiera działania ratownicze, gdy siły powiatu są niewystarczające;

— krajowym — który koordynuje i wspiera działania ratownicze, gdy siły województwa są niewystarczające.

Gotowość operacyjna sił i środków KSRG, w szczególności dyspozycyjność, wyszkolenie i wyposażenie w sprzęt ratowniczy, umożliwia ich dysponowanie w trybie pilnym według kryterium obszaru chronionego, to znaczy sił i środków niezbędnych do likwidacji lub ograniczania powstałego nagłego zagrożenia, mogących przybyć na miejsce zdarzenia w najkrótszym czasie. Zakłada się, że sieć jednostek ochrony przeciwpożarowej umożliwia dotarcie sił ratowniczych do zagrożonej ludności w ciągu 15 min. do $85 \%$ populacji. Konstrukcja KSRG zakłada także, że procedury realizacji podstawowych zadań ratowniczych są dostosowane do specyfiki rodzaju zdarzeń, również masowych, lub katastrof. Niezależnie od sieci jednostek ochrony przeciwpożarowej, które są przygotowane w zakresie podstawowym do realizacji zadań w każdej dziedzinie ratownictwa, Państwowa Straż Pożarna posiada w swych zasobach wydzielone siły i środki do realizowania specjalistycznych czynności ratowniczych poprzez wysoce specjalistyczny sprzęt ratowniczy oraz ponadstandardowe wyszkolenie strażaków PSP. Wydzielone zasoby ratownicze skupione są w 165 specjalistycznych grupach ratowniczych. Wyznaczone siły i środki z obszaru całego kraju skupione są w ramach Centralnego Odwodu Operacyjnego. Gdy siły i środki, dysponowane przez stanowisko kierowania Państwowej Straży Pożarnej, podmiotów KSRG i innych podmiotów uczestniczących w działaniu ratowniczym są niewystarczające, czynności ratownicze realizują również siły i środki podmiotów KSRG zadysponowane z obszaru województwa przez właściwego terenowo komendanta wojewódzkiego Państwowej Straży Pożarnej. Natomiast gdy siły i środki podmiotów KSRG dysponowane przez komendanta wojewódzkiego Państwowej Straży Pożarnej są niewystarczające, czynności ratownicze realizują również podmioty KSRG zadysponowane z obszaru kraju przez Komendanta Głównego Państwowej Straży Pożarnej. W 2017 roku jednostki ochrony przeciwpożarowej (funkcjonujące w KSRG) były dysponowane i interweniowały w 519902 zdarzeniach $^{5}$.

Należy zwrócić uwagę, że funkcjonowanie KSRG jest oparte na trzech fazach - elementach działania: prognozowaniu, rozpoznawaniu i zwalczaniu za-

${ }^{5}$ Komenda Główna Państwowej Straży Pożarnej, https://www.straz.gov.pl/panstwowa_straz_ pozarna/krajowy_system_ratowniczo_gasniczy (dostęp: 2.09.2018). 
grożeń. Elementy te warto zapamiętać, ponieważ ich istnienie można dostrzec w sposobie funkcjonowania zarządzania kryzysowego.

Zarządzanie kryzysowe w stosunku do krajowego systemu ratowniczo-gaśniczego jest znacznie „młodszym systemem”. Wprawdzie już pod koniec lat 90. ubiegłego wieku w retoryce odnoszącej się do sfery bezpieczeństwa mówiło się o reagowaniu kryzysowym, a także pojawiały się akty prawne regulujące działanie państwa w sytuacjach nadzwyczajnych, na przykład ustawa z dnia 18 kwietnia 2002 roku o stanie klęski żywiołowej ${ }^{6}$. Jednak sam termin zarządzania kryzysem nie był powszechnie stosowany ani umocowany prawnie. Wieloletnie doświadczenia w walce z sytuacjami nadzwyczajnymi, kryzysowymi, w tym wnioski z powodzi z 1997 roku, wskazały na dalszą potrzebę uregulowania zagadnień bezpieczeństwa wewnętrznego, w szczególności w odniesieniu do obszaru zarządzania kryzysowego, w jednym akcie prawnym. Tym samym ta problematyka znalazła uzasadnienie w przygotowaniu projektu, a następnie wprowadzeniu w życie ustawy z dnia 27 kwietnia 2007 roku o zarządzaniu kryzysowym ${ }^{7}$ (dalej: ustawa o zarządzaniu kryzysowym). Uznano, że jednolity akt prawny pomoże uregulować funkcjonowanie faktycznie istniejącego, lecz rozproszonego systemu, doprecyzuje zakres zadań i odpowiedzialności podmiotów, a tym samym podniesie skuteczność prawidłowego funkcjonowania państwa w zakresie ochrony mieszkańców przed zagrożeniami. Ustawa o zarządzaniu kryzysowym ujednoliciła system zarządzania kryzysowego mający na celu przeciwdziałanie zagrożeniom, reagowanie na zagrożenia i usuwanie ich skutków. Założyła działania prewencyjne i nadzwyczajne ze strony organów administracji publicznej oraz Sił Zbrojnych RP w sytuacjach nadzwyczajnych, które nie spełniają przesłanek do wprowadzenia zapisanych w prawie stanów nadzwyczajnych, takich jak stan wojenny, stan wyjątkowy i stan klęski żywiołowej. Intencją ustawodawcy było, aby dzięki ustawie o zarządzaniu kryzysowym stworzyć możliwość wdrażania mechanizmów, które pozwolą na zapewnienie skutecznego monitorowania stanu bezpieczeństwa, przewidywanie i szybkie wykrywanie zagrożeń oraz reagowanie na zagrożenia, ich eliminację lub ograniczenie, a także usuwanie skutków.

Ustawa stworzyła ramy prawne do poprawy stanu bezpieczeństwa powszechnego przez zwiększenie efektywności działania organów administracji publicznej w sytuacjach kryzysowych. Pojęcie bezpieczeństwa powszechnego obejmuje zarówno ochronę życia i zdrowia obywateli, jak również ochronę infrastruktury krytycznej. Instrumentem osiągania przez organy administracji publicznej właściwego poziomu przygotowania do działań w sytuacjach kryzysowych jest całokształt przedsięwzięć planistycznych zdefiniowanych w ustawie jako „planowanie cywilne”. Regulacja nałożyła także zadania na organy administracji publicznej,

${ }^{6}$ Ustawa z dnia 18 kwietnia 2002 roku o stanie klęski żywiołowej (tekst jedn. Dz.U. z 2017 r. poz. 1897).

${ }^{7}$ Ustawa z dnia 26 kwietnia 2007 roku o zarządzaniu kryzysowym (tekst jedn. Dz.U. z 2018 r. poz. $1401 \mathrm{ze}$ zm.). 
siły zbrojne oraz właścicieli i posiadaczy infrastruktury krytycznej. Uznano, że niezbędne jest określenie organów właściwych w sprawach zarządzania kryzysowego, a także ustalenie ich zadań i zasad działania. Założono, że utrzymywanie profesjonalnych struktur zarządzania kryzysowego w pełnej gotowości do przeciwdziałania tego rodzaju zagrożeniom pozwala na prewencyjne likwidowanie ich źródeł, sprawne współdziałanie przy ich eliminowaniu oraz na szybkie usuwanie skutków takich zdarzeń. Ustawa określiła rolę i zadania Prezesa Rady Ministrów, Rady Ministrów, poszczególnych ministrów i wojewodów, starostów (na potrzeby tej ustawy uzyskujących status organów, analogicznie do przepisów ustawy o stanie klęski żywiołowej) i wójtów (burmistrzów i prezydentów miast). $\mathrm{Na}$ mocy ustawy, na poziomie wojewódzkim, powiatowym i gminnym zostały powołane zespoły opiniodawczo-doradcze, których podstawowym zadaniem jest wspieranie wykonywania zadań z zakresu zarządzania kryzysowego przez właściwe organy administracji publicznej. Zespół taki powołano także na poziomie centralnym - jest to Rządowy Zespół Zarządzania Kryzysowego ${ }^{8}$. Składa się on z ministrów odpowiadających za zadania strategiczne dla bezpieczeństwa państwa i dziedziny życia społecznego i gospodarczego podatne na występowanie zagrożeń, a także szefów służb specjalnych oraz innych podmiotów. Zespół jest organem opiniodawczo-doradczym $w$ sprawach inicjowania i koordynowania działań Rady Ministrów w zakresie zarządzania kryzysowego, natomiast ostateczne uprawnienia stanowiące nadal przysługują Radzie Ministrów, zgodnie z obowiązującą Konstytucją RP.

Ustawa o zarządzaniu kryzysowym powołała centra zarządzania kryzysowego na szczeblu centralnym, wojewódzkim i samorządowym. Tylko na poziomie gminnym, ze względu na często mały obszar działania, założono, że tworzenie centrów nie jest obligatoryjne. Na szczeblu centralnym utworzono Rządowe Centrum Bezpieczeństwa ${ }^{9}$, nakładając na nie obowiązek wykonywania podstawowych zadań z zakresu zarządzania kryzysowego. Są to między innymi:

- realizacja spraw z zakresu planowania cywilnego;

- monitorowanie potencjalnych zagrożeń;

— uruchamianie, w przypadku zaistnienia zagrożeń, procedur związanych z zarządzaniem kryzysowym;

— współpraca ze strukturami Organizacji Traktatu Północnoatlantyckiego i Unii Europejskiej oraz innymi organizacjami międzynarodowymi;

— zapewnienie obiegu informacji między krajowymi i zagranicznymi organami i strukturami zarządzania kryzysowego.

Ustawa wprowadziła także dwa istotne pojęcia, które przed jej powstaniem nie były precyzyjnie zdefiniowane: planowanie cywilne i infrastruktura krytyczna.

\footnotetext{
${ }^{8}$ Ustawa z dnia 26 kwietnia 2007 roku o zarządzaniu kryzysowym, art. 8 ust. 1.

${ }^{9}$ Ustawa z dnia 26 kwietnia 2007 roku o zarządzaniu kryzysowym, art. 10 ust. 1.
} 
Planowanie cywilne ${ }^{10}$ — jak już wspomniano - to całokształt przedsięwzięć planistycznych, które stanowią element zarządzania kryzysowego. Polega ono głównie na opracowywaniu planów, w tym planów reagowania kryzysowego, i programów mających na celu optymalne wykorzystanie dostępnych zasobów w sytuacjach zagrożeń oraz w czasie stanów nadzwyczajnych lub wojny w zakresie zapobiegania sytuacjom kryzysowym, przygotowanie do przejmowania nad nimi kontroli, a także reagowanie w sytuacjach kryzysowych oraz odtwarzanie infrastruktury i przywracanie jej pierwotnego charakteru. Planowanie cywilne zakłada również działania w zakresie wspierania Sił Zbrojnych Rzeczypospolitej Polskiej w razie konieczności ich użycia oraz planowanie wykorzystania Sił Zbrojnych Rzeczypospolitej Polskiej do realizacji zadań z zakresu zarządzania kryzysowego.

$\mathrm{Z}$ kolei infrastruktura krytyczna ${ }^{11}$ została zdefiniowana jako systemy oraz wchodzące $\mathrm{w}$ ich skład, powiązane $\mathrm{z}$ sobą funkcjonalnie obiekty (w tym obiekty budowlane), urządzenia, instalacje i usługi kluczowe dla bezpieczeństwa państwa i jego obywateli oraz służące zapewnieniu sprawnego funkcjonowania organów władzy i administracji publicznej, a także instytucji i przedsiębiorców. Zgodnie z zapisami ustawy ${ }^{12}$ właściciele oraz posiadacze samoistni i zależni obiektów, instalacji lub urządzeń infrastruktury krytycznej mają obowiązek ich ochrony, w szczególności przez przygotowanie i wdrażanie - stosownie do przewidywanych zagrożeń - planów ochrony infrastruktury krytycznej oraz utrzymywanie własnych systemów rezerwowych zapewniających bezpieczeństwo i podtrzymujących funkcjonowanie tej infrastruktury do czasu jej pełnego odtworzenia. Ustawa na mocy rozporządzenia szczegółowego nałożyła na te podmioty obowiązek stworzenia planów ochrony infrastruktury krytycznej jako najważniejszych dokumentów planistycznych w tym zakresie.

Scharakteryzowane obszary zadaniowe - krajowy system ratowniczo-gaśniczy oraz zarządzanie kryzysowe - są uregulowane w dwóch odrębnych aktach prawnych. Można odnieść wrażenie lub spotkać się z opiniami, że skoro ustawodawca takie obszary wyodrębnił, to automatycznie rozdzielił je, nadając im niezależny od siebie charakter. Zdarza się, że nawet instytucje (organy) wykonujące zadania publiczne związane z zapewnieniem bezpieczeństwa wskazują na brak powiązań KSRG z zarządzaniem kryzysowym. Należy jednak podkreślić, że powiązanie tych elementów systemu bezpieczeństwa wewnętrznego jednak istnieje, a istnienie tego powiązania wynika wprost właśnie ze wskazanych przepisów prawa.

Ustawa z dnia 24 sierpnia 1991 roku o ochronie przeciwpożarowej w art. 14 nakłada zadania na organy administracji, w tym wojewodę i starostę. Organy te, odpowiednio na obszarze województwa lub powiatu, określają zadania krajowe-

${ }^{10}$ Ustawa z dnia 26 kwietnia 2007 roku o zarządzaniu kryzysowym, art. 3 pkt 4.

${ }^{11}$ Ustawa z dnia 26 kwietnia 2007 roku o zarządzaniu kryzysowym, art. 3 pkt 2.

12 Ustawa z dnia 26 kwietnia 2007 roku o zarządzaniu kryzysowym, art. 6 ust. 5. 
go systemu ratowniczo-gaśniczego, koordynują jego funkcjonowanie i kontrolują wykonywanie wynikających z tego określenia zadań, a w sytuacjach nadzwyczajnych zagrożeń życia, zdrowia lub środowiska kierują tym systemem ${ }^{13}$. Natomiast treść art. 14 ust. 4 przytoczonej ustawy stanowi, że wojewoda i starosta wykonują swoje zadania — z obszaru KSRG — przy pomocy odpowiednio wojewódzkiego i powiatowego zespołu zarządzania kryzysowego, które działają na podstawie ustawy o zarządzaniu kryzysowym. Ustawodawca jednoznacznie wskazał, że prawidłowa realizacja zadań KSRG przez wojewodę i starostę będzie możliwa przy pomocy zespołu doradczego realizującego zadania z zarządzania kryzysowego. Do podstawowych zadań zespołów zarządzania kryzysowego (na każdym poziomie administracyjnym) należy w szczególności:

— ocena występujących i potencjalnych zagrożeń mogących mieć wpływ na bezpieczeństwo publiczne i prognozowanie tych zagrożeń;

- przygotowywanie propozycji działań i przedstawianie wniosków dotyczących wykonania, zmiany lub zaniechania działań ujętych w planie zarządzania kryzysowego;

— przekazywanie do wiadomości publicznej informacji związanych z zagrożeniami;

— opiniowanie planu zarządzania kryzysowego ${ }^{14}$.

Istotna jest także obligatoryjna — wskazana ustawowo — konstrukcja tych zespołów. Na poziomie wojewódzkim w skład zespołu wchodzi wojewoda jako przewodniczący, kierownik komórki organizacyjnej właściwej w sprawach zarządzania kryzysowego w urzędzie wojewódzkim jako zastępca przewodniczącego, a także inne osoby wybrane przez wojewodę w zależności od potrzeb spośród kierowników zespolonych służb, inspekcji i straży wojewódzkich, osób zatrudnionych w urzędzie wojewódzkim lub w jednostkach organizacyjnych służb, inspekcji i straży wojewódzkich oraz osób zatrudnionych w Państwowym Gospodarstwie Wodnym Wody Polskie, a także Instytucie Meteorologii i Gospodarki Wodnej. W skład zespołu wojewódzkiego wchodzi również szef wojewódzkiego sztabu wojskowego lub jego przedstawiciel, a także może wchodzić przedstawiciel samorządu województwa, wyznaczony przez marszałka województwa. Dodatkowo skład zespołu wojewódzkiego mogą budować inne osoby zaproszone przez przewodniczącego ${ }^{15}$. Taka otwarta konstrukcja umożliwia modelowanie i dostosowywanie kompozycji tego gremium do potrzeb wykonywania zadań przez organ.

Powiatowy zespół zarządzania kryzysowego kierowany jest przez starostę. W skład tego zespołu wchodzą członkowie powołani spośród osób zatrudnionych w starostwie powiatowym, powiatowych jednostkach organizacyjnych lub jed-

\footnotetext{
${ }^{13}$ Ustawa z dnia 24 sierpnia 1991 roku o ochronie przeciwpożarowej, art. 14 ust. 3.

14 Ustawa z dnia 26 kwietnia 2007 roku o zarządzaniu kryzysowym, art. 14 ust. 8.

15 Ustawa z dnia 26 kwietnia 2007 roku o zarządzaniu kryzysowym, ust. 9.
} 
nostkach organizacyjnych stanowiących aparat pomocniczy kierowników zespolonych służb, inspekcji i straży powiatowych oraz przedstawiciele społecznych organizacji ratowniczych ${ }^{16}$. Starosta może także zaprosić do pracy w zespole inne osoby. Należy podkreślić, jak już wspomniano, że zadania zespołu powiatowego są tożsame z zadaniami zespołu wojewódzkiego.

Jak widać, zarówno zadania zespołów zarządzania kryzysowego, jak i ich skład, obejmują szerokie spektrum zagadnień związanych z bezpieczeństwem. Tym samym logiczne jest powiązanie tych zespołów z zadaniami KSRG, które w swojej istocie również obejmują rozległy zakres przedmiotowy. Nie można mieć także wątpliwości co do istnienia powiązania systemów i ich wzajemnego uzupełniania - bez rozstrzygania potencjalnego sporu, który system jest ważniejszy. Przytoczone przepisy, a także pragmatyka funkcjonowania organów administracji i instytucji wykonujących zadania na rzecz bezpieczeństwa wskazują, że KSRG powinien być ściśle zespolony z zarządzaniem kryzysowym.

To wzajemne powiązanie wynika także z faz działania obu systemów. Jak już wspomniano, w krajowym systemie ratowniczo-gaśniczym wyodrębnia się trzy fazy wykonywania zadań: prognozowanie, rozpoznawanie i zwalczani $\mathrm{e}^{17}$, a wszystkie fazy odnoszą się do postępowania z zagrożeniami — wszystkimi zagrożeniami przypisanymi do KSRG. W zarządzaniu kryzysowym przyjęto istnienie czterech faz - nie są one wprost nazwane fazami, lecz ich istnienie wynika z ustawowej definicji samego pojęcia zarządzania kryzysowego. Jest to zatem działalność organów administracji publicznej, będąca elementem kierowania bezpieczeństwem narodowym, która polega na zapobieganiu sytuacjom kryzysowym, przygotowaniu do przejmowania nad nimi kontroli w drodze zaplanowanych działań, reagowaniu w wypadku wystąpienia sytuacji kryzysowych, usuwaniu ich skutków oraz odtwarzaniu zasobów i infrastruktury krytycznej ${ }^{18}$.

Warto zwrócić uwagę na pewną zbieżność działania obu systemów w odniesieniu do wskazanych faz. KSRG prognozuje zagrożenia i je rozpoznaje - to ciągłość czynności i działań, które mają na celu niedopuszczenie do wystąpienia zdarzeń. Istotą tych faz jest takie postępowanie, które w maksymalnym stopniu, w ramach wydolności systemu, będzie zapobiegać występowaniu zdarzeń, tak aby wejście w ostatnią fazę — zwalczanie - miało miejsce jak najrzadziej. W początkowym cyklu działania systemu zarządzania kryzysowego mamy do czynienia z zapobieganiem i przygotowaniem. Działanie na tych etapach polega na realizacji przedsięwzięć zmierzających do ograniczenia prawdopodobieństwa lub całkowitego wykluczenia wystąpienia sytuacji kryzysowych albo w znacznym stopniu ograniczającego ich skutki. Ponadto przygotowanie to podejmowa-

\footnotetext{
${ }^{16}$ Ustawa z dnia 26 kwietnia 2007 roku o zarządzaniu kryzysowym art. 17 ust. 6.

${ }^{17}$ Ustawa z dnia 24 sierpnia 1991 roku o ochronie przeciwpożarowej art. 2 pkt 4.

18 Ustawa z dnia 26 kwietnia 2007 roku o zarządzaniu kryzysowym art. 2.
} 
nie działań planistycznych na wszystkich szczeblach administracji, dotyczących sposobów reagowania na czas wystąpienia różnego rodzaju sytuacji kryzysowych w celu zmniejszenia negatywnych skutków tych zdarzeń. Obie te fazy to takie postępowanie, które pozwoli, na ile to możliwe, nie dopuścić do etapu reagowania - zwalczania danego zagrożenia. Mamy co prawda do czynienia z użyciem innych słów, jednak z perspektywy działań praktycznych czynności w tych fazach są zbieżne - na przykład opracowywanie planów czy procedur, które wykonywane jest przez podmioty zarówno KSRG, jak i zarządzania kryzysowego, czy przygotowywanie i utrzymywanie sił i środków w gotowości do działań. W wypadku przejścia do reagowania — zwalczania, pomimo różnorodności podmiotów wchodzących w skład obu systemów, działanie ich wszystkich ma doprowadzić do udzielania pomocy poszkodowanym, zapobieżenia rozwoju występującego zagrożenia oraz ograniczenia strat i zniszczeń. Cel jest, jak widać, ten sam — usunięcie zagrożenia.

Wiele lat funkcjonowania tych systemów potwierdza ich wzajemne powiązanie i uzupełnianie. Celem nadrzędnym ich funkcjonowania jest działanie na rzecz bezpieczeństwa obywateli i państwa. Systemy nie mogą z sobą rywalizować i wzajemnie się wykluczać - na przykład przez wadliwie stworzone przepisy. Jedynym zjawiskiem, w którego kontekście może być mowa o walce obu tych systemów, lecz nie wzajemnej, są zagrożenia bezpieczeństwa.

\section{Bibliografia}

Bezpieczeństwo wewnętrzne $w$ działaniach terenowej administracji publicznej, red. A. Chajbowicz, T. Kocowski, Wrocław 2009.

\section{Wykaz aktów prawnych}

Ustawa z dnia 24 sierpnia 1991 roku o ochronie przeciwpożarowej (tekst jedn. Dz.U. z 2018 r. poz. 620 ze zm.).

Ustawa z dnia 24 sierpnia 1991 roku o Państwowej Straży Pożarnej (tekst jedn. Dz.U. z 2018 r. poz. 1313).

Ustawa z dnia 18 kwietnia 2002 roku o stanie klęski żywiołowej (tekst jedn. Dz.U. z 2017 r. poz. 1897 ze zm.).

Ustawa z dnia 26 kwietnia 2007 roku o zarządzaniu kryzysowym (tekst jedn. Dz.U. z 2018 r. poz. 1401 ze zm.). 


\title{
Źródła internetowe
}

https://www.straz.gov.pl/panstwowa_straz_pozarna/krajowy_system_ratowniczo_gasniczy

\section{National firefighting and rescue system in crisis management}

\begin{abstract}
Summary
The article characterizes the essence of cooperation and dependence between the National rescue and fire extinguishing system and the crisis management system. The study indicates the origin of the indicated systems, the legal basis for their functioning, and the administration bodies performing the tasks. The purpose of the publication is to describe the structure of the rescue and firefighting system and crisis management together with the presentation of their common elements. The author describes, amongst other features, the operating phases of individual systems, taking into account convergent and corresponding elements. The postulates that the systems complement each other, and the primary objective of their functioning is to act for the benefit of citizens' and state security.
\end{abstract}

Keywords: state security, internal security, crisis management, rescue system, public administration, governor (of province), voivode, district head, staroste. 